Article

\title{
Modified Johnston Failure Criterion from Rock Mechanics to Predict the Ultimate Strength of Fiber Reinforced Polymer (FRP) Confined Columns
}

\author{
Zehra Canan Girgin \\ Architecture Faculty, Yildiz Technical University, Istanbul 34349, Turkey; \\ E-Mail: zcgirgin@yildiz.edu.tr; Tel.: +90-212-383-2616; Fax: +90-212-261-0549
}

Received: 31 October 2013; in revised form: 16 December 2013 / Accepted: 17 December 2013 / Published: 30 December 2013

\begin{abstract}
The failure criteria from rock mechanics, Hoek-Brown and Johnston failure criteria, may be extended and modified to assess the ultimate compressive strength of axially loaded circular fiber reinforced polymer (FRP)-confined concrete columns. In addition to the previously modified Hoek-Brown criterion, in this study, the Johnston failure criterion is extended to scope of FRP-confined concrete, verified with the experimental data and compared with the significant relationships from the current literature. Wide-range compressive strengths from 7 to $108 \mathrm{MPa}$ and high confinement ratios up to 2.0 are used to verify the ultimate strengths in short columns. The results are in good agreement with experimental data for all confinement levels and concrete strengths.
\end{abstract}

Keywords: confined concrete; fiber-reinforced polymer; axial strength; rock mechanics; Mohr-Coulomb; Hoek-Brown; Johnston

\section{Introduction}

Fiber reinforced polymer (FRP) composites are increasingly being applied for the seismic retrofitting and strengthening of reinforced concrete structures. Currently, FRPs are primarily used for two types of applications. One is a thin layer of FRP jacket applied for seismic rehabilitation of damaged and undamaged reinforced concrete structures, and another is the application of FRP tubes in rebuilding and new construction. FRP composites are suitable for use in coastal and marine structures as well as civil infrastructure facilities due to their properties such as high strength-to-weight ratio, high-tensile strength and modulus, corrosion resistance and durability. FRP confinement provides 
superior seismic performance with enhancing lateral confinement level, energy absorption capacity and ductility [1-5]. Nowadays, new types of cheaper and eco-friendly materials (e.g., recycled pet bottles, etc.) are investigated [6] in addition to common FRP materials (carbon, glass or aramid fiber reinforced plastics; CFRP, GFRP, AFRP, respectively).

Most empirical confinement models address the Mohr-Coulomb failure criterion for actively (hydrostatic pressure) or passively (steel, FRP) confined concrete [3,7-14]. This study focuses on two failure criteria from rock mechanics, the Hoek-Brown's [15] and especially the Johnston's failure criteria [16], for FRP-confined concrete. The Mohr-Coulomb criterion is valid only in the compression region [17], whereas Hoek-Brown's and Johnston's failure criteria from rock mechanics exist both in compressive and tensile regions to complete it (Figure 1). Previously, in order to extend the scope to concrete, the Hoek-Brown's and Johnston's criteria were successfully verified to predict the ultimate strength in high strength (60-132 MPa) concrete specimens under active confining pressure [17]. More recently, the Hoek-Brown criterion was applied to reinforced concrete and FRP- confined circular columns by the author [18]. This study addresses the applicability of other failure criterion, the Johnston failure criterion, from rock mechanics. The criterion is validated for FRP-confined circular short columns through the wide-range experimental data (7 to $108 \mathrm{MPa}$ ) from the current literature. The comparisons confirm the applicability of the Johnston failure criterion to FRP composites as well.

Figure 1. Mohr-Coulomb, Johnston and Hoek-Brown's failure envelope to estimate the ultimate strength under triaxial compression.

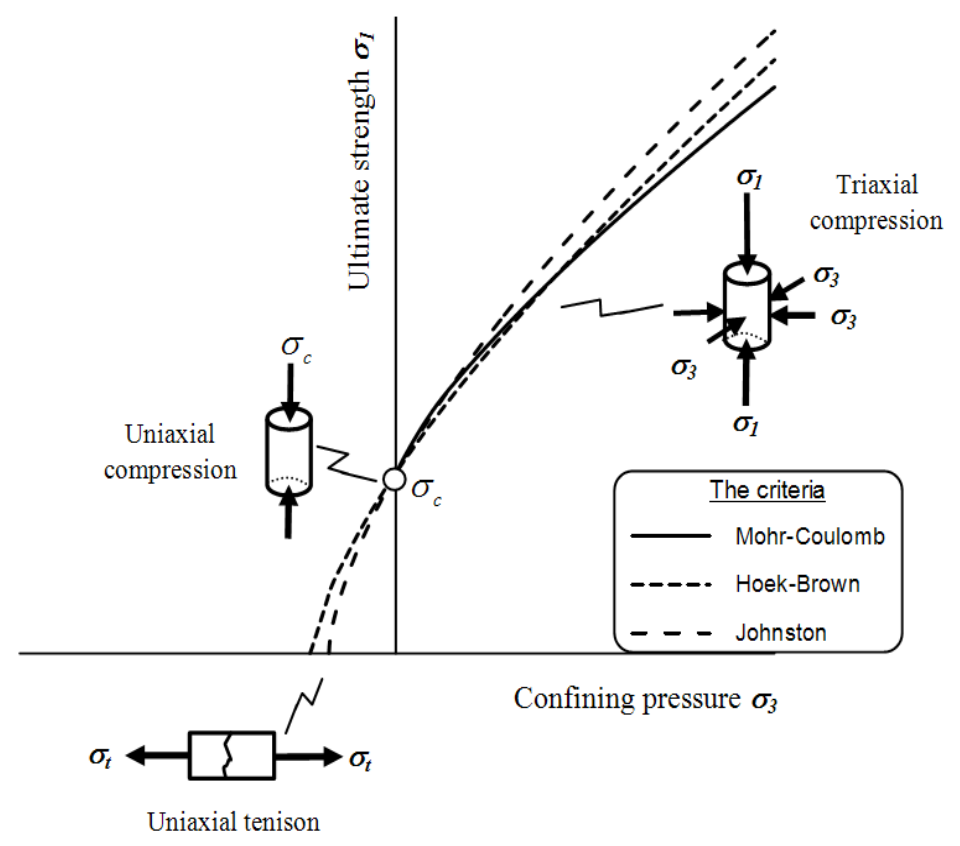

\section{Literature Survey and Database}

Considerable research has been devoted to FRP-confined circular columns and numerous models have been proposed $[1-4,11-14,18-26]$. The common experimental data to predict ultimate (confined) strength are especially in the range of 30 to $50 \mathrm{MPa}$ [11,25-33]. In this study, a database involved in short columns $(L / D=1.6$ to 2.9 , most of them are 2$)$ [3,11,24-42] was deployed regarding the confinement levels from 0.03 up to 2.0 by including AFRP, CFRP, and GFRP jacketing. The average 
value of nominally identical specimens in each test group was used to decrease scattering and error in the analyses. In addition, the data from observed lateral stresses or coupon test results were used to improve the reliability. In terms of concrete cylinder strength $f_{c o}$, the averaged database covers 116 data for FRP-wrapped cylinders from 7 to $108 \mathrm{MPa}$ [3,24-27,30-32,35-42] and 19 data for FRP tube encased cylinders from 29.6 to $45.4 \mathrm{MPa}$ [11,28,29,33,34]. In addition, 56 averaged data [6,14,23,43-45] from 17 to $80 \mathrm{MPa}$ were used for calibration.

\section{Overview to Confinement Models with FRP}

Under triaxial compressive stresses, the columns are subjected to major compressive stresses $\sigma_{1}$ uniformly applied along the axial axis of the column and lateral confining pressure $\sigma_{3}$ (Figure 1). This pressure may be provided by passive means such as steel (hoops, ties, spirals, jackets, etc.) and FRP (sheets, tubes, etc.) confinement around the concrete core or actively through hydrostatic pressure. On the contrary of steel, FRP behaves elastically until failure. The inward radial pressure increases with the lateral expansion of the concrete, so that the assumption of constant confining pressure is no longer valid. The models $[7,8,46-48]$ developed for steel confinement may unsafely overestimate the strength of FRP-confined columns.

In FRP confined columns, the fibers are generally aligned primarily along the hoop direction to provide the confinement of concrete while the fibers in the axial direction provide the flexural strength and stiffness. While the concrete is stressed triaxially, the FRP jacket is loaded uniaxially and, at the FRP-concrete interface, the confining radial pressure $\sigma_{3}$ (Figure 2) develops by:

$$
f_{l}=\sigma_{3}=\frac{2 t \sigma_{f r p}}{D}
$$

where $t, D, \sigma_{f r p}$ denote the thickness of FRP, the diameter of concrete core and the hoop tensile strength of FRP, respectively.

Figure 2. Scheme of confining action for (a) concrete; (b) Fiber reinforced polymer (FRP) composite.
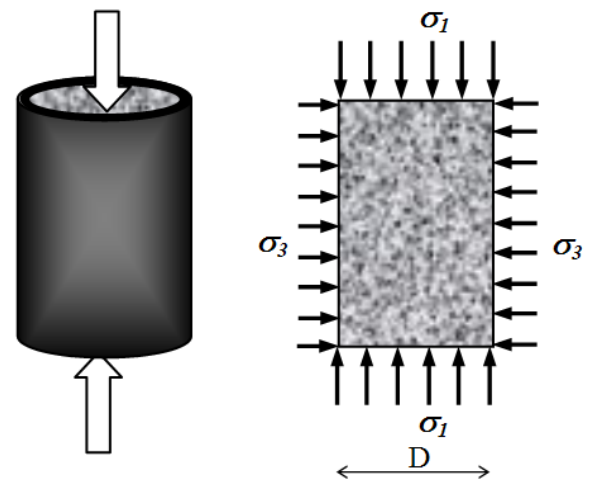

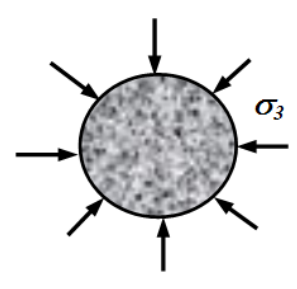

(a) Concrete

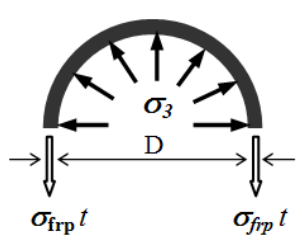

(b) FRP composite

The Mohr-Coulomb failure criterion frequently used for confined concrete is essentially based on triaxial soil data:

$$
\sigma_{1}=\frac{2 c \cos \phi}{1-\sin \phi}+\frac{1+\sin \phi}{1-\sin \phi} \sigma_{3}, \sigma_{1} \geq \sigma_{3}
$$


here $\sigma_{1}$ signifies the major principal stress at failure (ultimate strength), $\sigma_{3}$ is the minor principal stress (confining pressure), $c$ is the cohesive strength of soil, and $\phi$ is the internal-friction angle. Unconfined strength $\left(f_{l}=\sigma_{3}=0\right)$ is defined as:

$$
f_{c o}=\sigma_{1}=\frac{2 c \cos \phi}{1-\sin \phi}
$$

The positive effect of confinement on concrete cylinders was first observed and modelled by Richart et al. [7] by defining the internal-friction angle $\phi$ as $37^{\circ}$. Then Goodman [49] suggested $\phi$ in the range of $36^{\circ}-45^{\circ}$ for most of concrete strengths, Rochette and Labossière formulated $\phi$ and $c$ [30].

The confinement effectiveness coefficient $k$ is defined in terms of $\phi$ :

$$
k=\frac{1+\sin \phi}{1-\sin \phi}
$$

and Equation (2) may be expressed to assess the ultimate strength $f_{c c}$ of confined concrete:

$$
f_{c c}=f_{c o}+k f_{l}
$$

and often in the following normalized form:

$$
\frac{f_{c c}}{f_{c o}}=1+k \frac{f_{l}}{f_{c o}}
$$

where $f_{c c} / f_{c o}$ is described as the strengthening ratio. Richart et al. [7] who suggested $k$ value as 4.1 corresponding to $\phi=37^{\circ}$ and then many authors have widely used these forms [8-14].

Saatcioglu and Razvi [47] found that the coefficient $k$ decreases with increasing confining pressure by approaching a constant value in high lateral stresses. While Candappa et al. [50] proposed $k=5.3$ for low confinement levels, Ansari and $\mathrm{Li}$ [10] found $k=2.6$ for high confinement levels. Dahl [51] has shown that the traditional value of $k=4.1$ overestimates the ultimate strength for the confinement ratios exceeding 0.5. For FRP-confined concrete, while some authors suggested a constant value for $k[6,14,22,52-54]$, according to other authors, $k$ should be a function decreasing with the confinement ratio $[3,11-13,20,55]$.

As a great number of relationships according to Mohr-Coulomb criterion have been proposed so far, in this study, only the variation of $k$ is displayed for FRP-wrapped or FRP tube encased specimens. For the averaged database of this study, two significantly different cases are observed especially for FRP-wrapped specimens (Figure 3). In the first case, a specific trend with a dashed line is under consideration and while $k$ value is high in low confinement levels it declines toward a constant value of 1.8 in high confinement levels. For the second case, there are data scattering in the confinement ratios lower than about 0.7 . It may be suggested that $k$ has either a conservative value of about 2 or lower and variable values within the dotted curve. The dotted line converges towards the first trend at medium confinement levels. Spoelstra and Monti [13] previously defined lower effectiveness for $f_{l} / f_{c o}<0.07$ and expressed that the confinement effectiveness is never greater than 3 and that it reaches maximum at about $f_{l} / f_{c o}<0.3$. According to Li [56], both insufficient coefficient and higher concrete strength may lead to lower confinement effectiveness. Recently Teng et al. [57] defined $f_{l} / f_{c o}$ to be the product of the confinement stiffness ratio and strain ratio. In the literature, $k$ coefficient was expressed in terms 
of normalized lateral jacket rigidity [24], confinement pressure nonlinearly [28], confinement pressure and cylinder concrete strength nonlinearly [3,12,13], and more recently normalized axial rigidity [20].

Figure 3. The variation of confinement efficiency in FRP-wrapped and FRP-encased specimens.

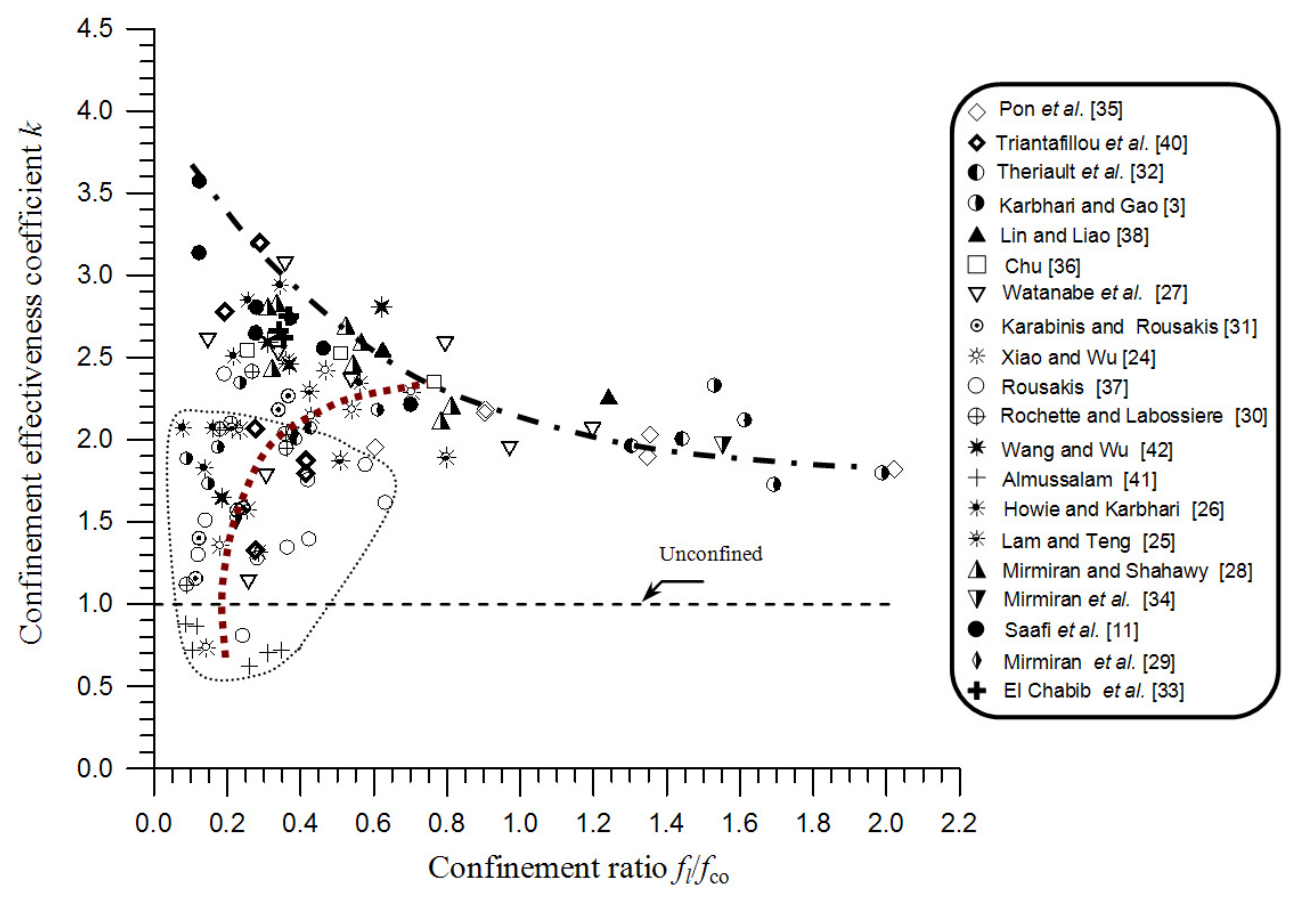

\section{Modified Failure Criteria from Rock Mechanics}

\subsection{Hoek-Brown Failure Criterion}

Hoek and Brown [15] introduced a failure criterion for rocks $\left(\sigma_{\mathrm{c}} \geq 20 \mathrm{MPa}\right)$ :

$$
\sigma_{1}=\sigma_{3}+\sigma_{c}\left(m \frac{\sigma_{3}}{\sigma_{c}}+s\right)^{0.5}
$$

where $\sigma_{c}$ is the uniaxial-unconfined-compressive strength of intact rock specimens, $m$ and $s$ are the material constants. The value of $m$ that governs the curvature of failure envelope depends on the type of rock, e.g., the representative value of $m$ is 15 for sandstone and quartzite. The other constant $s$ describes the discontinuities in rock and ranges from 0 (heavily jointed rocks) to 1 (intact rocks).

For confined concrete, it can be shown that Equation (7) may take the form:

$$
f_{c c}=f_{l}+\left(s f_{c o}^{2}+m f_{c o} f_{l}\right)^{1 / 2}
$$

Equation (8) can further be expressed as [17]:

$$
Y=m f_{c o} X+s f_{c o}^{2}=A_{o} X+B_{o}
$$

where $Y=\left(f_{c c}-f_{l}\right)^{2} ; X=f_{l}, A_{\mathrm{o}}=m f_{c o}, B_{o}=s f_{c o}^{2}$

Concrete containing no discontinuity can be treated as intact rock material $(s=1)$. Using $f_{l}$ and $f_{c c}$ values resulting from triaxial tests on confined concrete, $Y$ and $X$ values are determined. Then, the material constant $m$ may be assigned from the linear regression analysis between $Y$ and $X$ values and 
thus the failure envelope is described. In the pure tension case $f_{c c}=0 \rightarrow f_{l}=-f_{t}$ where $f_{t}$ is the uniaxial-direct-tensile strength (Figure 1).

In this failure criterion adapted from rock mechanics, the first step is to precisely predict $m$ constant. The predicted $m$ values regarding the active and FRP confinement are displayed according to the strength ranges in Table 1. For FRP confined concrete, while $m$ is 4.8 to 3.3 in normal strength range (20 to $40 \mathrm{MPa})$, it has a very low value $(m=0.1)$ in the high-strength concrete especially over $80 \mathrm{MPa}$ [18]. Meanwhile, it should be mentioned for cylinder strengths over $108 \mathrm{MPa}$ the accuracy of prediction may be decreased due to very low and constant $m$ coefficient. As for actively confined concrete, the highest $m$ value $(m=13)$ is under consideration [17] and approaches to the lower range of rocks [15]. The variations [18] between confinement effectiveness (strengthening ratio) and confinement ratio are demonstrated for differently confined concrete (FRP, steel, FRP + steel) and rock specimens in Figure 4.

Table 1. The variation of predicted $m$ constant through two confining techniques.

\begin{tabular}{cccccccc}
\hline \multirow{2}{*}{$\begin{array}{c}\text { Confinement } \\
\text { f }\end{array}$} & $\begin{array}{c}\boldsymbol{f}_{\boldsymbol{c o}} \\
(\mathbf{M P a})\end{array}$ & $\boldsymbol{m}$ & $\begin{array}{c}\text { Number of } \\
\text { data }(\boldsymbol{n})\end{array}$ & $\begin{array}{c}\text { IAE } \\
(\mathbf{\%})\end{array}$ & $\bar{\Delta} \mathbf{( \% )}$ & Source of data \\
\hline $\begin{array}{c}\text { FRP } \\
\text { wrapped or } \\
\text { encased tube }\end{array}$ & 0 & $\begin{array}{c}7-18 \\
20-82\end{array}$ & $6.34-0.076 f_{c o}$ & 104 & 4.6 & $+4.6,-4.9$ & {$[3,11,24-34,36-42]$} \\
\hline $\begin{array}{c}\text { Active } \\
\text { pressure }\end{array}$ & $83-108$ & 0.1 & 7 & 5.2 & $+5.2,-5.5$ & {$[37,41]$} \\
\hline
\end{tabular}

$\bar{\Delta}=$ average deviation, $\left[\Delta=\left(O_{\mathrm{i}}-P_{\mathrm{i}}\right) / O_{\mathrm{i}} \times 100, \%\right] ; O_{\mathrm{i}}, P_{\mathrm{i}}=$ respectively observed and predicted ultimate compressive strength; IAE $=$ Integral Absolute Error, $I A E=\Sigma \frac{\left|O_{i}-P_{i}\right|}{\Sigma O_{i}} \times 100 \%[17,18]$.

Figure 4. Failure envelopes of intact rock specimens and concrete confined by different confining materials. Reprinted with permission from [18]. Copyright 2009. ACI.

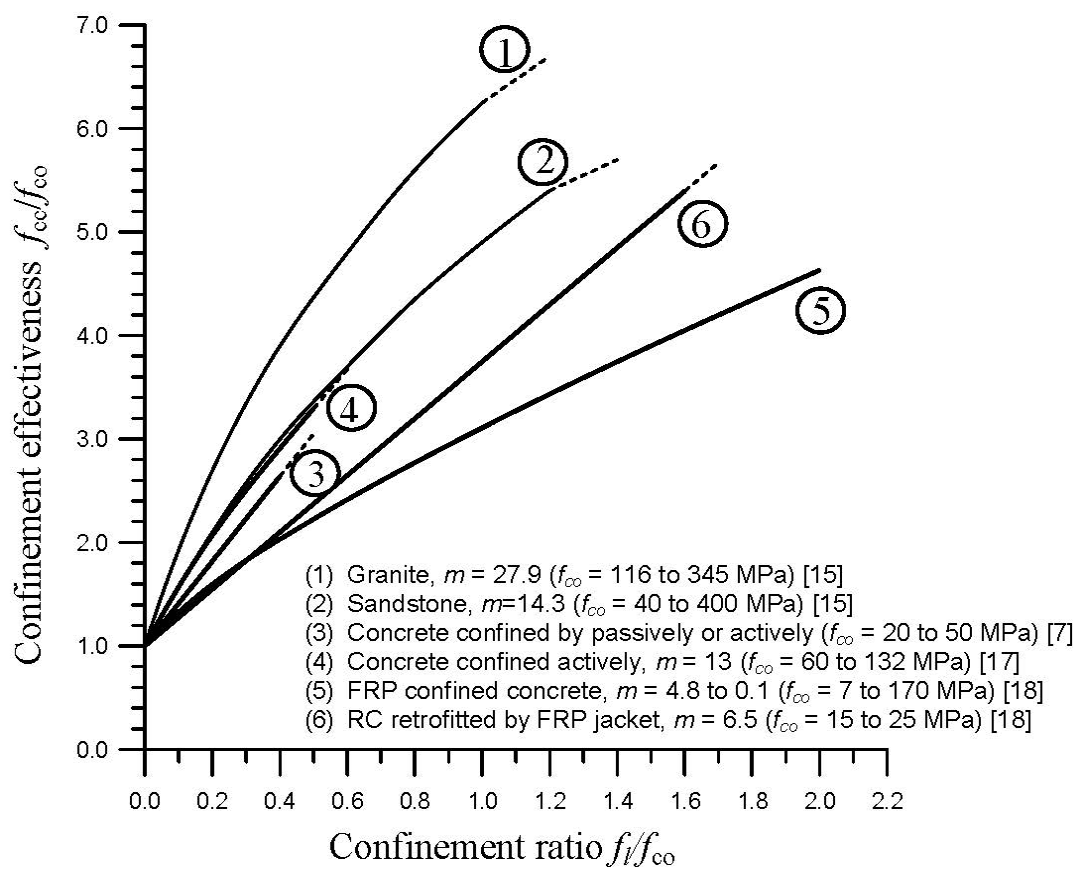




\subsection{Johnston's Failure Criterion}

Johnston's failure criterion [16] is valid for all intact soils and rocks under triaxial compression ranging from $0.008 \mathrm{MPa}$ (lightly overconsolidated clays) to $600 \mathrm{MPa}$ (extremely hard rocks). It is defined as:

$$
\frac{\sigma_{1}}{\sigma_{c}}=\left(1+\frac{M}{B} \cdot \frac{\sigma_{3}}{\sigma_{c}}\right)^{B}
$$

where $M$ and $B$ correspond to the material coefficients. $B$ defines the nonlinearity of the strength criterion and $M$ describes the slope of the failure envelope at $f_{l}=0$. They are reasonably related to the compressive strength $\sigma_{c}$. Johnston expressed $B$ coefficient as a parabolic curve:

$$
B=1-0.0172\left(\log \sigma_{c}\right)^{2},\left(0.008 \mathrm{MPa} \leq \sigma_{c} \leq 600 \mathrm{MPa}\right)
$$

in which the unit of $\sigma_{c}$ is $\mathrm{kPa}$. It can be realized that $B$ converges to $1\left(\sigma_{c} \rightarrow 1\right)$ for normally consolidate clays, to 0.5 for rocks. Johnston identified $M$ coefficient with parabolic curves in four groups regarding geomaterial formations.

If the Johnston criterion is extended to confined concrete, Equation (10) may be adapted for confined concrete as follows:

$$
\frac{f_{c c}}{f_{c o}}=\left(1+\frac{M}{B} \times \frac{f_{l}}{f_{c o}}\right)^{B}
$$

$B$ coefficient minimizing the IAE ratio was previously determined to be 0.5 for high strength concrete $\left(f_{c o}=60-132 \mathrm{MPa}\right)$ under active pressure (Table 2) and $M / B$ ratio was defined in terms of splitting tensile and compressive strength [17] and this ratio seems to be a function of the uniaxial

\begin{tabular}{|c|c|c|c|c|c|c|c|c|}
\hline $\begin{array}{c}\text { Confining } \\
\text { material }\end{array}$ & $\begin{array}{c}f_{c o} \\
(\mathbf{M P a})\end{array}$ & $B$ & $M$ & $\begin{array}{c}f_{c o} \\
(\mathbf{M P a})\end{array}$ & $\begin{array}{c}\text { Number } \\
\text { of data }\end{array}$ & $\begin{array}{l}\text { IAE } \\
(\%)\end{array}$ & $\bar{\Delta}(\%)$ & Source of data \\
\hline \multirow{5}{*}{$\begin{array}{c}\text { FRP } \\
\text { wrapped } \\
\text { or } \\
\text { encased } \\
\text { tube }\end{array}$} & $7-24$ & \multirow{5}{*}{$\begin{array}{c}\text { Equation } \\
\text { (13) }\end{array}$} & $\begin{array}{l}\text { Equation } \\
\text { (14a) }\end{array}$ & $7-18$ & 24 & 3.1 & $+3.0,-3.3$ & {$[3,32,35,40]$} \\
\hline & \multirow{4}{*}{$25-108$} & & \multirow{4}{*}{$\begin{array}{c}\text { Equation } \\
\text { (14b) }\end{array}$} & $21-30$ & 21 & 4.0 & $+4.5,-4.2$ & $\begin{array}{c}{[27,28,34,36,} \\
38-40]\end{array}$ \\
\hline & & & & $31-39$ & 41 & 5.2 & $+4.2,-5.4$ & $\begin{array}{l}{[3,11,24-26} \\
28,31,32,42]\end{array}$ \\
\hline & & & & $40-52$ & 37 & 5.8 & $+5.5,-6.2$ & $\begin{array}{c}{[24,29,30,33,37,} \\
39,42]\end{array}$ \\
\hline & & & & $70-108$ & 12 & 2.9 & $+2.0,-3.8$ & {$[37,41]$} \\
\hline $\begin{array}{c}\text { Active } \\
\text { pressure }\end{array}$ & $60-132$ & 0.5 & [17] & $60-132$ & 71 & 5.8 & $+6.3,-6.3$ & {$[58,59]$} \\
\hline
\end{tabular}
compressive strength $f_{c o}$ and the type of rock.

Table 2. The variation of predicted $B$ and $M$ coefficients.

In this study, the Johnston criterion is modified and extended to FRP-confined concrete. Herein, Equation (13) derived from the classical relationship Equation (11) is employed for $B$ coefficient by covering all the strength ranges: 


$$
B=1-0.0172\left(\log f_{c o}\right)^{2}, f_{c o} \text { in } \mathrm{kPa}
$$

For $M$ coefficient, the following correlations were developed with min. IAE ratios and deviations:

$$
\begin{gathered}
M=0.0035 f_{c o}^{2}-0.056 f_{c o}+2.83\left(7 \mathrm{MPa} \leq f_{c o}<25 \mathrm{MPa}, R=0.98\right) \\
M=0.0003 f_{c o}^{2}-0.076 f_{c o}+5.46\left(25 \mathrm{MPa} \leq f_{c o}<108 \mathrm{MPa}, R=0.99\right)
\end{gathered}
$$

Thus, by knowing $B$ and $M$ coefficients, the failure envelope can be established easily. For the strength levels lower than about $f_{c o}=25 \mathrm{MPa}, M$ values decreases from 3.8 down to about 2.6 $\left(f_{c o}=7.3 \mathrm{MPa}\right)$. From $25 \mathrm{MPa}$ to upper strength levels, $M$ values gradually decrease, e.g., $M$ coefficient is 0.75 for $f_{c o}=108 \mathrm{MPa}$.

\section{Evaluations and Comparisons of Modified Johnston Failure Criterion}

In this section, the prediction capability of modified Johnston criterion will be verified through the averaged database $(n=135)$ and with the current models in Table 3. Data were classified according to strength ranges as groups and all the models were individually investigated according to these ranges to be independent from the definition range of the model. The number of data for each strength range is $24,21,41,37,12$, respectively.

The Integral Absolute Error (IAE) previously defined [17,18] and average deviations $(\bar{\Delta})$ were used in comparisons. When comparing different models, the smallest value of the IAE can be judged as the most reliable one. IAE ratio $10 \%$ may be regarded as the limit for a acceptable prediction.

High IAE and $\bar{\Delta}$ ratios of the models developed for steel confinement [7,46-48] usually indicate an over-estimation for FRP confined concrete. In FRP models, the IAE ratio usually increases in high-strength concrete especially for $f_{c o} \geq 70 \mathrm{MPa}[3,4,11-13,32,50,54,57,60]$ or in poor strength levels lower than $20 \mathrm{MPa}$ [4,12,22,55,60]. Karbhari and Gao [3] and Saafi et al.'s models [11] have good assessment capability beyond the strength range as well. Within the models based on Mohr-Coulomb criterion, the most reliable results for constant $k$ coefficient are provided with $k=2[32,53,54]$ for the range 7-52 MPa. Rousakis et al.'s model [20] was individually defined for carbon and glass jackets, and in this study the predictions were executed only for carbon sheets with different elastic modulus and very good accuracy was achieved especially for $f_{c o} \geq 30 \mathrm{MPa}$. Modified Johnston criterion, similar to previously modified Hoek-Brown criterion, yields the best prediction with the smallest IAE ratios $(4.7 \%)$ and deviations $(-4.8 \%,+4.1 \%)$ (Tables $1-3)$ for all the strength ranges $\left(f_{c o}=7\right.$ to $\left.108 \mathrm{MPa}\right)$ from low to high confinement ratios.

By comparing the test results, the failure envelopes of modified Johnston criterion are displayed for specific strength levels of 7.32, 18, 30, 39, 52 and 81.4 MPa in Figures 5-7. In these comparisons, the data in the same strength level from calibration database [6,14,23,43-45] was also employed with $c l b$ symbol. It is interesting that the Johnston criterion modified for common FRP jackets (carbon, glass, aramid) may enable a good prediction for recently developed PEN fibers [6] as well (Figure 6). The predicted results of modified Johnston criterion exhibit very good agreement with database and calibration data (Figure 8). 
Table 3. Prediction of ultimate compressive strength in FRP-confined concrete.

\begin{tabular}{|c|c|c|c|c|c|c|c|}
\hline \multirow{4}{*}{ Source and strength range } & \multirow{4}{*}{ Model } & \multicolumn{6}{|c|}{ Range of cylinder compressive strength, MPa } \\
\hline & & $7-18$ & 21-30 & 31-39 & $40-52$ & 70-108 & All data \\
\hline & & 24 & 21 & 41 & 37 & 12 & 135 \\
\hline & & \multicolumn{6}{|c|}{ IAE, $\%(\bar{\Delta}, \%)$} \\
\hline $\begin{array}{c}\text { Richart et al. }[7] \\
\text { Fardis and Khalili [1] } \\
\left(f_{c o}=20-50 \mathrm{MPa}\right)\end{array}$ & $\frac{f_{c c}}{f_{c o}}=1+4.1 \frac{f_{l}}{f_{c o}}$ & $\begin{array}{c}78.9 \\
(-71.5)\end{array}$ & $\begin{array}{c}35.4 \\
(-30.3)\end{array}$ & $\begin{array}{c}30.9 \\
(-28.4)\end{array}$ & $\begin{array}{c}37.9 \\
(-36.3)\end{array}$ & $\begin{array}{c}57.8 \\
(-56.4)\end{array}$ & $\begin{array}{l}42.3 \\
(-40)\end{array}$ \\
\hline $\begin{array}{l}\text { Fafitis and Shah }[8] \\
\left(f_{c o}=20-66 \mathrm{MPa}\right)\end{array}$ & $\frac{f_{c c}}{f_{c o}}=1+\left(1.15+\frac{21}{f_{c o}}\right) \frac{f_{l}}{f_{c o}}$ & $\begin{array}{c}29.6 \\
(-36.7) \\
\end{array}$ & $\begin{array}{c}9.9 \\
(-9.8) \\
\end{array}$ & $\begin{array}{c}9.1 \\
(-10.4) \\
\end{array}$ & $\begin{array}{c}14.6 \\
(-16.1,+2.1) \\
\end{array}$ & $\begin{array}{c}40.7 \\
(-40.2) \\
\end{array}$ & $\begin{array}{c}18 \\
(-18.8,+2.1) \\
\end{array}$ \\
\hline Mander et al. $[46]^{\mathrm{a}}$ & $\frac{f_{c c}}{f_{c}^{\prime}}=2.254 \sqrt{1+7.94 \frac{f_{l}}{f_{c}^{\prime}}}-2 \frac{f_{l}}{f_{c o}^{\prime}}-1.254$ & $\begin{array}{c}13.6 \\
(-22.4,+10)\end{array}$ & $\begin{array}{c}16.5 \\
(-19.2,+3.1)\end{array}$ & $\begin{array}{c}27.5 \\
(-28.1)\end{array}$ & $\begin{array}{l}36.5 \\
(-37) \\
\end{array}$ & $\begin{array}{c}64.8 \\
(-63.9) \\
\end{array}$ & $\begin{array}{c}33.6 \\
(-32.5) \\
\end{array}$ \\
\hline $\begin{array}{l}\text { Saatcioglu and Razvi }[47,48]^{\text {a }} \\
\qquad\left(f_{c o}=30-124 \mathrm{MPa}\right)\end{array}$ & $\frac{f_{c c}}{f_{c o}^{\prime}}=1+6.7 \frac{f_{l}^{0.83}}{f_{c o}^{\prime}}$ & $\begin{array}{c}78 \\
(-79.9) \\
\end{array}$ & $\begin{array}{c}36.6 \\
(-34.1) \\
\end{array}$ & $\begin{array}{c}34.5 \\
(-33.3)\end{array}$ & $\begin{array}{c}39.2 \\
(-38.8)\end{array}$ & $\begin{array}{c}55.6 \\
(-54.8)\end{array}$ & $\begin{array}{c}43.6 \\
(-43.9) \\
\end{array}$ \\
\hline $\begin{array}{l}\text { Karbhari and Gao }[3] \\
\qquad\left(f_{c o}=38 \mathrm{MPa}\right)\end{array}$ & $\frac{f_{c c}}{f_{c o}}=1+2.1\left(\frac{f_{l}}{f_{c o}}\right)^{0.87}$ Model II & $\begin{array}{c}5.3 \\
(-6.9,+2.1) \\
\end{array}$ & $\begin{array}{c}6.0 \\
(-1.0,+6.4) \\
\end{array}$ & $\begin{array}{c}5.0 \\
(-6.9,+4.2) \\
\end{array}$ & $\begin{array}{c}7.3 \\
(-8.5,+5.1) \\
\end{array}$ & $\begin{array}{c}28.1 \\
(-27.6) \\
\end{array}$ & $\begin{array}{c}9.9 \\
(-11.4,+4.9) \\
\end{array}$ \\
\hline $\begin{array}{l}\text { Samaan et al. }[4] \\
\left(f_{c o}=29-32 \mathrm{MPa}\right)\end{array}$ & $\frac{f_{c c}}{f_{c o}}=1+6 \frac{f_{l}^{0.7}}{f_{c o}}$ & $\begin{array}{c}21.6 \\
(-29.6) \\
\end{array}$ & $\begin{array}{c}4.1 \\
(-6.1,+2.2) \\
\end{array}$ & $\begin{array}{c}7.6 \\
(-9.7,+1.2) \\
\end{array}$ & $\begin{array}{c}9.8 \\
(-10,+1.6) \\
\end{array}$ & $\begin{array}{l}26.3 \\
(-26) \\
\end{array}$ & $\begin{array}{c}12.1 \\
(-15.4,+2.0) \\
\end{array}$ \\
\hline Saafi et al. $[11]\left(f_{c o}=38 \mathrm{MPa}\right)$ & $\frac{f_{c c}}{f_{c o}}=1+2.2\left(\frac{f_{l}}{f_{c o}}\right)^{0.84}$ & $\begin{array}{c}7.3 \\
(-7.7) \\
\end{array}$ & $\begin{array}{c}4.3 \\
(-2.4,+5.5) \\
\end{array}$ & $\begin{array}{c}5.5 \\
(-7.6,+2.9) \\
\end{array}$ & $\begin{array}{c}9.9 \\
(-11.8,+2.4) \\
\end{array}$ & $\begin{array}{c}32.4 \\
(-31.9) \\
\end{array}$ & $\begin{array}{c}11.3 \\
(-12,+4) \\
\end{array}$ \\
\hline $\begin{array}{l}\text { Spoelstra and Monti [13] } \\
\qquad\left(f_{c o}=30-50 \mathrm{MPa}\right)\end{array}$ & $\frac{f_{c c}}{f_{c o}}=0.2+3\left(\frac{f_{l}}{f_{c o}}\right)^{0.5}$ & $\begin{array}{c}6.5 \\
(-10.5,+4.1) \\
\end{array}$ & $\begin{array}{c}3.8 \\
(-3.1,+4.6) \\
\end{array}$ & $\begin{array}{c}7.3 \\
(-5.8,+4.7) \\
\end{array}$ & $\begin{array}{c}10.9 \\
(-11.6,+1.9) \\
\end{array}$ & $\begin{array}{c}29.4 \\
(-28.4)\end{array}$ & $\begin{array}{c}14.4 \\
(-11.4,+4.2) \\
\end{array}$ \\
\hline $\begin{array}{l}\text { Miyauchi et al. }[22] \\
\left(f_{c o}=33-45 \mathrm{MPa}\right)\end{array}$ & $\frac{f_{c c}}{f_{c o}}=1+3 \frac{f_{l}}{f_{c o}}$ & $\begin{array}{c}39.1 \\
(-35.1) \\
\end{array}$ & $\begin{array}{c}15.2 \\
(-12,+4.6) \\
\end{array}$ & $\begin{array}{c}11.6 \\
(-11.8,+4.1) \\
\end{array}$ & $\begin{array}{c}16.7 \\
(-16.2) \\
\end{array}$ & $\begin{array}{c}37.3 \\
(-36.4) \\
\end{array}$ & $\begin{array}{c}20 \\
(-19.5,+4.4) \\
\end{array}$ \\
\hline
\end{tabular}


Table 3. Cont.

\begin{tabular}{|c|c|c|c|c|c|c|c|}
\hline \multirow{4}{*}{ Source and strength range } & \multirow{4}{*}{ Model } & \multicolumn{6}{|c|}{ Range of cylinder compressive strength, $\mathrm{MPa}$} \\
\hline & & $7-18$ & 21-30 & 31-39 & $40-52$ & 70-108 & All data \\
\hline & & 24 & 21 & 41 & 37 & 12 & 135 \\
\hline & & \multicolumn{6}{|c|}{ IAE, $\%(\bar{\Delta}, \%)$} \\
\hline $\begin{array}{c}\text { Toutanji [12] modified } \\
\quad\left(f_{c o}=31 \mathrm{MPa}\right)\end{array}$ & $\frac{f_{c c}}{f_{c o}}=1+2.3\left(\frac{f_{l}}{f_{c o}}\right)^{0.85}$ & $\begin{array}{l}10.3 \\
(-11) \\
\end{array}$ & $\begin{array}{c}3.8 \\
(-3.3,+4.5) \\
\end{array}$ & $\begin{array}{c}6.3 \\
(-7.7,+2.1) \\
\end{array}$ & $\begin{array}{c}11.2 \\
(-12.3,+2.6) \\
\end{array}$ & $\begin{array}{c}34 \\
(-33.4) \\
\end{array}$ & $\begin{array}{c}12.4 \\
(-12.6,+3.4) \\
\end{array}$ \\
\hline $\begin{array}{l}\text { Theriault and Neale [32] } \\
\qquad\left(f_{c o}=32-44 \mathrm{MPa}\right) \\
\text { Lam and Teng [53] } \\
\left(f_{c o}=27-55 \mathrm{MPa}\right) \\
\text { Campione and Miraglia [54] } \\
\left(f_{c o}=20-44 \mathrm{MPa}\right)\end{array}$ & $\frac{f_{c c}}{f_{c o}}=1+2 \frac{f_{l}}{f_{c o}}$ & $\begin{array}{c}4.9 \\
(-5.1,+2.5)\end{array}$ & $\begin{array}{l}11.4 \\
(+12)\end{array}$ & $\begin{array}{c}7.5 \\
(-3.5,+7.8)\end{array}$ & $\begin{array}{c}6.2 \\
(-6.9,+5.5)\end{array}$ & $\begin{array}{c}18.7 \\
(-18.2)\end{array}$ & $\begin{array}{c}9.5 \\
(-9.8,+7.8)\end{array}$ \\
\hline $\begin{array}{l}\text { Girgin }[18] \text { Hoek-Brown } \\
\text { criterion }\left(f_{c o}=7-108 \mathrm{MPa}\right)\end{array}$ & $\begin{array}{c}f_{c c}=f_{l}+\left(f_{c o}{ }^{2}+m \cdot f_{c o} \cdot f_{l}\right)^{1 / 2} \\
m=2.9\left(f_{c o}=7-18 \mathrm{MPa}\right) \\
m=6.34-0.076\left(f_{c o}=18-82 \mathrm{MPa}\right) \\
m=0.1\left(f_{c o}=83-108 \mathrm{MPa}\right)\end{array}$ & $\begin{array}{c}4.2 \\
(-4.2,+4.5)\end{array}$ & $\begin{array}{c}3.4 \\
(-2.2,+4.3)\end{array}$ & $\begin{array}{c}4.6 \\
(-4.9,+4.6)\end{array}$ & $\begin{array}{c}5.6 \\
(-5.8,+4.7)\end{array}$ & $\begin{array}{c}5.1 \\
(-5.0,+3.4)\end{array}$ & $\begin{array}{c}4.7 \\
(-4.5,+4.5)\end{array}$ \\
\hline $\begin{array}{l}\text { Wu and Zhou [60] based on } \\
\text { Hoek-Brown crit. } \\
\left(f_{c o}=18-80 \mathrm{MPa}\right)\end{array}$ & $\frac{f_{c c}}{f_{c o}}=\frac{f_{l}}{f_{c o}}+\left[\left(\frac{16.7}{f_{c o}^{0.42}}-\frac{f_{c o}^{0.42}}{16.7}\right) \frac{f_{l}}{f_{c o}}+1\right]^{1 / 2}$ & $\begin{array}{c}16.9 \\
(-20.5)\end{array}$ & $\begin{array}{c}4.1 \\
(-0.8,+5.6)\end{array}$ & $\begin{array}{c}4.7 \\
(-5.2,+4.9)\end{array}$ & $\begin{array}{c}5.8 \\
(-6.6,+4.2)\end{array}$ & $\begin{array}{c}18.2 \\
(-17.9)\end{array}$ & $\begin{array}{c}8.3 \\
(-11.2,+4.0)\end{array}$ \\
\hline $\begin{array}{c}\text { Mohamed and } \\
\text { Masmoudi }[61] \\
\left(f_{c o}=25-60 \mathrm{MPa}\right)\end{array}$ & $\frac{f_{c c}}{f_{c o}}=0.7+2.7\left(\frac{f_{l}}{f_{c o}}\right)^{0.7}$ & $\begin{array}{c}19.7 \\
(-14.4)\end{array}$ & $\begin{array}{c}12.7 \\
(-9.9,+15.2)\end{array}$ & $\begin{array}{c}12.0 \\
(-2.0,14.2)\end{array}$ & $\begin{array}{c}9.7 \\
(-10.3)\end{array}$ & $\begin{array}{c}15.4 \\
(-18.4)\end{array}$ & $\begin{array}{c}12.8 \\
(-13.4,+12.9)\end{array}$ \\
\hline $\begin{array}{l}\text { Fahmy and } \mathrm{Wu}[55] \\
\left(f_{c o}=25-170 \mathrm{MPa}\right)\end{array}$ & $\begin{array}{l}\frac{f_{c c}}{f_{c o}}=1+k_{1} \frac{f_{l}^{0.7}}{f_{c o}} k_{1}=4.5, k_{1}=3.75 \\
\left(f_{c o} \leq 40 \mathrm{MPa}, f_{c o}>40 \mathrm{MPa}\right)\end{array}$ & $\begin{array}{c}11.4 \\
(-14.4,+10.5) \\
\end{array}$ & $\begin{array}{c}12.87 \\
(-2.4,+12.4) \\
\end{array}$ & $\begin{array}{c}9.2 \\
(-8.8,+8.6) \\
\end{array}$ & $\begin{array}{c}11.3 \\
(-6.0,+10.6) \\
\end{array}$ & $\begin{array}{c}9.6 \\
(-10.4,+1.0) \\
\end{array}$ & $\begin{array}{c}10.6 \\
(-10.0,+10.3) \\
\end{array}$ \\
\hline
\end{tabular}


Table 3. Cont.

\begin{tabular}{|c|c|c|c|c|c|c|c|}
\hline \multirow{4}{*}{ Source and strength range } & \multirow{4}{*}{ Model } & \multicolumn{6}{|c|}{ Range of cylinder compressive strength, MPa } \\
\hline & & $7-18$ & 21-30 & 31-39 & $40-52$ & 70-108 & All data \\
\hline & & 24 & 21 & 41 & 37 & 12 & 135 \\
\hline & & \multicolumn{6}{|c|}{ IAE, $\%(\bar{\Delta}, \%)$} \\
\hline $\begin{array}{c}\text { Teng et al. }[57] \\
\left(f_{c o}=38-45.9 \mathrm{MPa}\right)\end{array}$ & $\begin{array}{l}\frac{f_{c c}}{f_{c o}}=1+3.3 \frac{f_{l}}{f_{c o}},\left(\frac{f_{l}}{f_{c o}} \geq 0.07\right) \\
\frac{f_{c c}}{f_{c o}}=1, \quad\left(\frac{f_{l}}{f_{c o}}<0.07\right)\end{array}$ & $\begin{array}{c}47.6 \\
(-41.0)\end{array}$ & $\begin{array}{c}19.2 \\
(-20,+4.08)\end{array}$ & $\begin{array}{c}12.6 \\
(-15.6,+5.8)\end{array}$ & $\begin{array}{c}13.9 \\
(-18.2,+5.8)\end{array}$ & $\begin{array}{c}42.8 \\
(-39.1)\end{array}$ & $\begin{array}{c}20.6 \\
(-23.1,+5.2)\end{array}$ \\
\hline $\begin{array}{c}\text { Rousakis [20] } \\
\left(f_{c o}=9-170 \mathrm{MPa}\right)\end{array}$ & $\frac{f_{c c}}{f_{c o}}=1+\left(\frac{\rho_{f} E_{f}}{f_{c o}}\right) \cdot\left(\frac{\alpha E_{f} 10^{-6}}{E_{f \mu}}+\beta\right)$ & $\begin{array}{c}10.2^{\mathrm{c}} \\
(-7.8,+10.8)\end{array}$ & $\begin{array}{c}11.4 \\
(-15.1,+8.5) \\
\end{array}$ & $\begin{array}{c}5.1 \\
(-6.3,+4.1) \\
\end{array}$ & $\begin{array}{c}6.7 \\
(-5.6,+6.1) \\
\end{array}$ & $\begin{array}{c}6.4 \\
(-6.3) \\
\end{array}$ & $\begin{array}{c}7.5 \\
(-7.8,+7,8) \\
\end{array}$ \\
\hline $\begin{array}{l}\text { This study-Johnston } \\
\text { criterion }\left(f_{c o}=7-108 \mathrm{MPa}\right)\end{array}$ & $\begin{array}{c}\frac{f_{c c}}{f_{c o}}=\left(1+\frac{M}{B} \cdot \frac{f_{l}}{f_{c o}}\right)^{B} \\
B: \text { Equation }(13) \\
M: \text { Equation }(14 \mathrm{a}) \\
\left(f_{c o}=7-24 \mathrm{MPa}\right) \\
M: \text { Equation }(14 \mathrm{~b}) \\
\left(f_{c o}=25-108 \mathrm{MPa}\right)\end{array}$ & $\begin{array}{c}3.1 \\
(-3.3,+3.0)\end{array}$ & $\begin{array}{c}4.0 \\
(-4.2,+4.5)\end{array}$ & $\begin{array}{c}5.2 \\
(-5.4,+4.2)\end{array}$ & $\begin{array}{c}5.8 \\
(-6.2,+5.5)\end{array}$ & $\begin{array}{c}2.9 \\
(-3.8,+2.0)\end{array}$ & $\begin{array}{c}4.7 \\
(-4.8,4.1)\end{array}$ \\
\hline
\end{tabular}

${ }^{a}$ Analysis was carried out by taking $f_{c o}^{\prime}=f_{c o}, f_{c o}^{\prime}=$ in-place unconfined compressive strength of concrete [the ratio of unconfined strength in-place; $f_{c o}^{\prime}$ in the column to standard cylinder strength $f_{c o}$ is generally taken as 0.85$] ;{ }^{\mathrm{b}} \rho_{f}=4 t_{f} / d, E_{f \mu}=10 \mathrm{MPa}$ (for units compliance); $\alpha=-0.336, \beta=0.0223$ for FRP sheets $; \alpha=-0.23, \beta=0.0195$ for FRP tube; $Y=f_{c d} / f_{c o}-1, X=\rho_{f} E_{f} f_{c o}, Y=A X$, carbon: $A=0.0151\left(E_{f}=234 \mathrm{GPa}\right), 0.0093\left(E_{f}=377 \mathrm{GPa}\right), 0.0021\left(E_{f}=640 \mathrm{GPa}\right)$, glass: $A=0.0187\left(E_{f}=80.1 \mathrm{GPa}\right)$;

${ }^{\mathrm{c}}$ In this study, predictions was carried out for only carbon sheets 234, 377 and $640 \mathrm{GPa}$. 
Figure 5. Verification of Johnston criterion for low-strength $\left(f_{c o}=7.32,18 \mathrm{MPa}\right)$ FRP confined concrete.

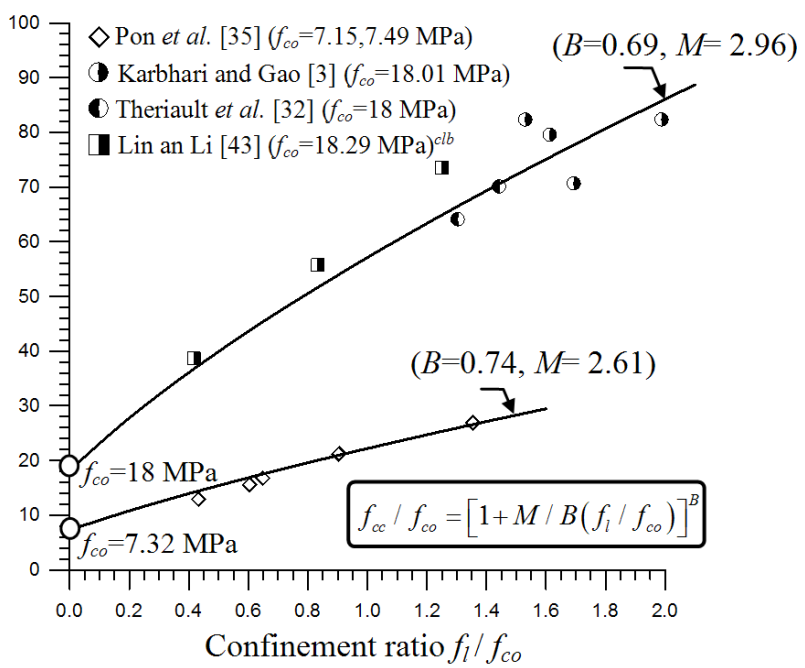

Figure 6. Verification of Johnston criterion for normal-strength $\left(f_{c o}=30\right.$ and $\left.39 \mathrm{MPa}\right) \mathrm{FRP}$ confined concrete.
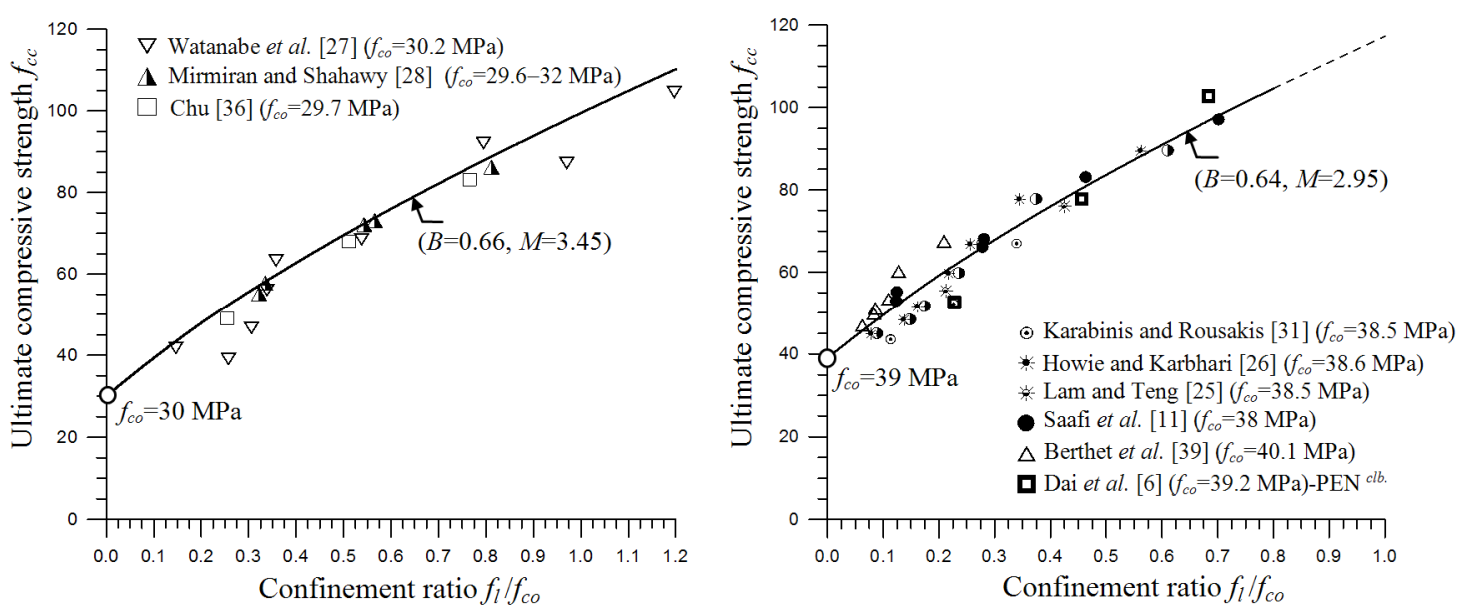

Figure 7. Verification of Johnston criterion for high-strength $\left(f_{c o}=52\right.$ and $\left.81.4 \mathrm{MPa}\right)$ FRP confined concrete.
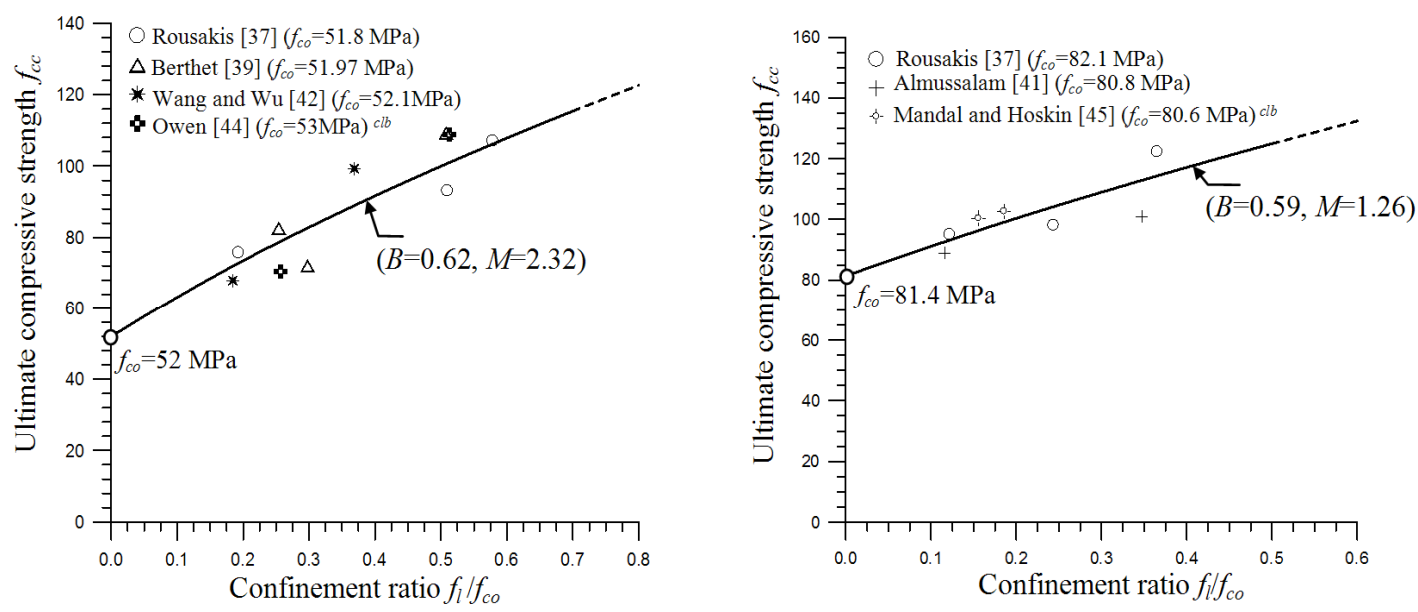
Figure 8. Predicted versus experimental ultimate compressive strengths according to modified Johnston criterion.

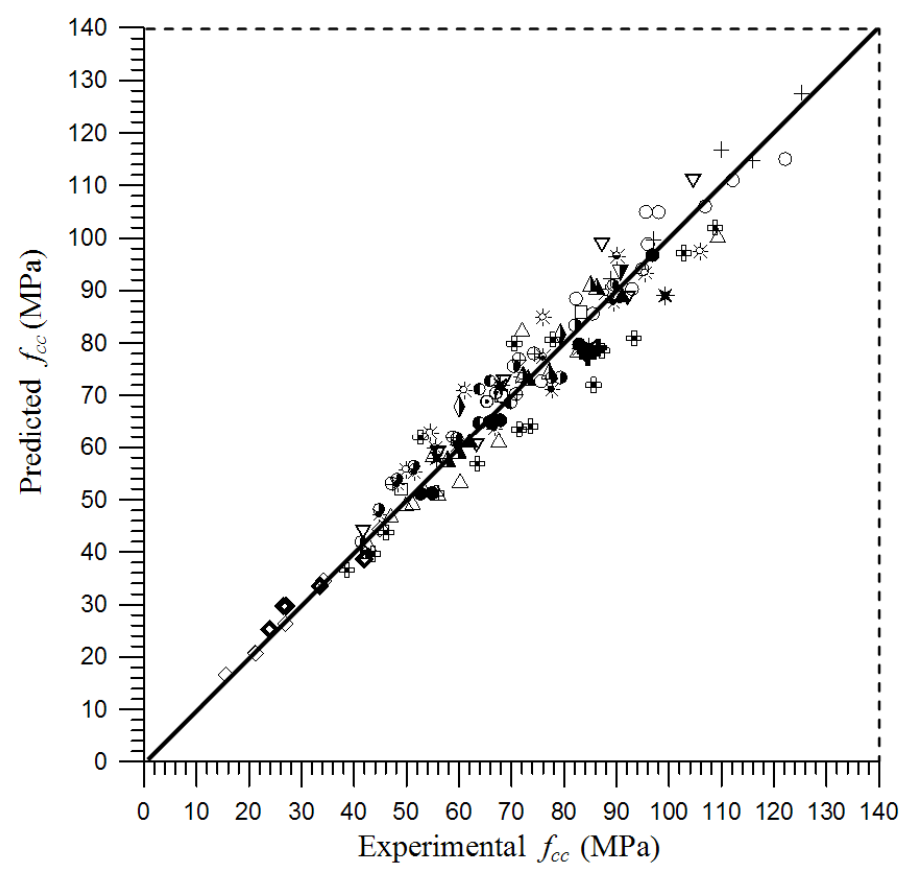

$\triangle$ Pon et al. [35]

$\diamond$ Triantafillou et al. [40]

- Theriault et al. [32]

- Karbhari and Gao [3]

$\Delta$ Lin and Liao [38]

$\square$ Chu [36]

$\nabla$ Watanabe et al. [27]

$\odot$ Karabinis and Rousakis [31]

* Xiao and Wu [24]

O Rousakis [37]

$\oplus$ Rochette and Labossiere [30]

* Wang and Wu [42]

+ Almussalam [41]

* Howie and Karbhari [26]

* Lam and Teng [25]

$\Delta$ Mirmiran and Shahawy [28]

$\nabla$ Mirmiran et al. [34]

- Saafi et al. [11]

- Mirmiran et al. [29]

+ El Chabib et al. [33]

$\triangle$ Berthet et al. [39]

Calibration data $[6,14,23,43-45]$

\section{Conclusions}

In this study, the Johnston failure criterion essentially developed for rock data were extended and modified to FRP-confined short columns. The averaged database $(n=135)$ from 7 to $108 \mathrm{MPa}$ and calibration data from 17 to $80 \mathrm{MPa}$ comprises the uniaxial strengths for FRP-tube encased concrete specimens as well as FRP-wrapped ones. The following conclusions can be drawn from the findings of this study:

- The material coefficients $B$ and $M$ of the Johnston failure criterion were defined in terms of cylinder compressive strength to be parabolic curves. The highest effectiveness $(M=3.75)$ is achieved for normal-strength concrete of about $25 \mathrm{MPa}$ like the modified Hoek-Brown criterion's $m$ coefficient. $M$ coefficient gradually decreases to high-strength concrete (e.g., $M=0.75$ for $\left.f_{c o}=108 \mathrm{MPa}\right)$.

- The Johnston failure criterion modified in this study yields the best prediction, like previously modified the Hoek-Brown failure criterion, in comparison with other current models. The predicted ultimate strengths are assigned with high accuracy $[\mathrm{IAE}=4.7 \%, \bar{\Delta}=(-4.8 \%,+4.1 \%)]$.

- This failure criterion may be modified regarding the recent eco-friendly recycled plastic materials (PEN, PET) as well.

\section{Conflicts of Interest}

The author declares no conflict of interest. 


\section{References}

1. Fardis, M.N.; Khalili, H. Concrete encased in fiberglass-reinforced plastic. ACI Struct. J. 1981, $78,440-445$.

2. Saadatmanesh, H.; Ehsani, M.R.; Li, M.W. Strength and ductility of concrete columns externally reinforced with fiber composite straps. ACI Struct. J. 1994, 91, 434-447.

3. Karbhari, V.M.; Gao, Y. Composite jacketed concrete under uniaxial compression-Verification of simple design equations. ASCE J. Mater. Civ. Eng. 1997, 9, 185-193.

4. Samaan, M.; Mirmiran, A.; Shahawy, M. Modeling of concrete confined by fiber composites. ASCE J. Struct. Eng. 1998, 124, 1025-1031.

5. Ozbakkaloglu, T.; Akın, E. Behavior of FRP-confined normal- and high-strength concrete under cyclic axial compression. ASCE J. Compos. Constr. 2012, 16, 451-463.

6. Dai, J.G.; Bai, Y.L.; Teng, J.G. Behaviour and modeling of concrete confined with FRP composites of large deformability. ASCE J. Compos. Constr. 2011, 15, 963-973.

7. Richart, E.; Brandtzaeg, A.; Brown, R.L. Failure of Plain and Spirally Reinforced Concrete in Compression; Bulletin 190; University of Illinois, Engineering Experimental Station: Champaign, IL, USA, 1929.

8. Fafitis, A.; Shah, S.P. Lateral Reinforcement for High-Strength Concrete Columns. In High-Strength Concrete; ACI SP-87; American Concrete Institute: Farmington Hills, MI, USA, 1985, pp. 213-232.

9. Razvi, S.R.; Saatcioglu, M. Confinement model for high-strength concrete. ASCE J. Struct. Eng. 1999, 125, 3281-3289.

10. Ansari, F.; Li, Q. High strength concrete subjected to triaxial compression. ACI Mater. J. 1998, 95, 747-755.

11. Saafi, M.; Toutanji, H.A.; Li, Z. Behaviour of concrete columns confined with fiber reinforced polymer tubes. ACI Mater. J. 1999, 96, 500-509.

12. Toutanji, H.A. Stress-strain characteristics of concrete columns externally confined with advanced fibre composite sheets. ACI Mater. J. 1999, 96, 397-402.

13. Spoelstra, M.R.; Monti, G. FRP-confined concrete model. ASCE J. Compos. Constr. 1999, 3, $143-150$.

14. Jiang, T.; Teng, J.G. Analysis-oriented stress-strain models for FRP-confined concrete. Eng. Struct. 2007, 29, 2968-2986.

15. Hoek, E.; Kaiser, P.K.; Bawden, W.F. Support of Underground Excavations in Hard Rock; A.A. Balkema: Rotterdam, Netherlands, 1995; p. 215.

16. Johnston, I.W. Comparison of two strength crieria for intact rock. ASCE J. Geotech. Eng. Div. 1985, 111, 1449-1454.

17. Girgin, Z.C.; Arıglu, N.; Arıglu, E. Evaluation of strength criteria for very-high-strength concretes under triaxial compression. ACI Struct. J. 2007, 104, 278-284.

18. Girgin, Z.C. A modified failure criterion to predict ultimate strength of circular columns confined by different materials. ACI Struct. J. 2009, 106, 800-809.

19. De Lorenzis, L.; Tepfers, R. Comparative study of models on confinement of concrete cylinders with fiber-reinforced polymer composites. ASCE J. Compos. Constr. 2003, 7, 219-237. 
20. Rousakis, T.C.; Rakitzis, T.D.; Karabinis, A.I. Design-oriented strength model for FRP-confined concrete members. ASCE J. Compos. Constr. 2012, 16, 615-625.

21. Ozbakkaloglu, T.; Lim, J.C. Axial compressive behavior of FRP-confined concrete: Experimental test database and a new design-oriented model. Compos. Part B 2013, 55, 607-634.

22. Miyauchi, K.; Inoue, S.; Kuroda, T.; Kobayashi, A. Strengthening effects of concrete columns with carbon fiber sheet. Trans. Jpn. Concr. Inst. 1999, 21, 143-150.

23. Ilki, A.; Kumbasar, N. Compressive behaviour of carbon fibre composite jacketed concrete with circular and non-circular cross-sections. J. Earth Eng. 2003, 7, 381-406.

24. Xiao, Y.; $\mathrm{Wu}, \mathrm{H}$. Compressive behavior of concrete confined by carbon fiber composite jackets. ASCE J. Mater. Civ. Eng. 2000, 12, 139-146.

25. Lam, L.; Teng, J.G. Ultimate condition of FRP-confined concrete. ASCE J. Compos. Constr. 2004, 8, 539-548.

26. Howie, I.; Karbhari, V.M. Effect of Materials Architecture on Strengthening Efficiency of Composite Wraps for Deteriorating Columns in the North-East. In Infrastructure: New Materials and Methods of Repair; Basham, K.D., Ed.; American Society of Civil Engineers: New York, NY, USA, 1994; pp. 199-206.

27. Watanabe, K.; Nakamura, H.; Honda, T.; Toyoshima, M.; Iso, M.; Fujimaki, T.; Kaneto, M.; Shirai, N. Confinement Effect of FRP Sheet on Strength and Ductility of Concrete Cylinders under Uniaxial Compression. In Proceedings of the 3rd International Symposium on Non-Metallic (FRP) Reinforcement for Concrete Structure, Sapporo, Japan, 14-16 October 1997; pp. 233-240.

28. Mirmiran, A.; Shahawy, M. Behavior of concrete columns confined by fiber composites. ASCE J. Struct. Eng. 1997, 123, 583-590.

29. Mirmiran, A.; Shahawy, M.; Samaan, M.; El Echary, H. Effect of column parameters on FRP-confined concrete. ASCE J. Compos. Constr. 1998, 2, 175-185.

30. Rochette, P.; Labossière, P. Axial testing of rectangular column models confined with composites. ASCE J. Compos. Constr. 2000, 4, 129-136.

31. Karabinis, A.I.; Rousakis, T.C. Concrete confined by FRP material: A plasticity approach. Eng. Struct. 2002, 24, 923-932.

32. Thériault, M.; Neale, K.W.; Claude, S. Fiber-reinforced polymer-confined circular concrete columns: Investigation of size and slenderness effects. ASCE J. Compos. Constr. 2004, 8, 323-331.

33. El Chabib, H.; Nehdi, M.; El Naggar, M.H. Behavior of SCC confined in short GFRP tubes. Cem. Concr. Compos. 2005, 27, 55-64.

34. Mirmiran, A.; Shahawy, M.; Beitleman, T. Slenderness limit for hybrid FRP-concrete columns. ASCE J. Compos. Constr. 2001, 5, 26-34.

35. Pon, T.H.; Li, Y.F.; Shih, B.J.; Han, M.S.; Chu, G.D.; Chiu, Y.J. Experiments of Scale Effects on the Strength of FRP Reinforced Concrete (in Chinese). In Proceedings of the 4th National Conference on Structural Engineering, Taipei, Taiwan, September 1998; pp. 2133-2140.

36. Chu, G.D. The Technology and Application of Composites in the Reinforcement of Structures in Civil Engineering. In Proceedings of the Technical Conference on Reinforced of RC Structure, Industry Technology Research Institute, Taipei, Taiwan, September 1998; p. 45. 
37. Rousakis, T. Experimental Investigation of Concrete Cylinders Confined by Carbon FRP Sheets, under Monotonic and Cyclic Axial Compressive Load; Chalmers University of Technology: Göteborg, Sweden, 2001; p. 87.

38. Lin, H.L.; Liao, C.I. Compressive strength of reinforced concrete-column confined by composite materials. Compos. Struct. 2004, 65, 239-250.

39. Berthet, J.F.; Ferrier, E.; Hamelin, P. Compressive behavior of concrete externally confined by composite jackets. Part A: Experimental study. Constr. Build. Mater. 2005, 19, 223-232.

40. Triantafillou, T.C.; Papanicolaou, C.G.; Zissimopoulos, P.; Laourdekis, T. Concrete confinement with textile-reinforced mortar jackets. ACI Struct. J. 2006, 103, 28-37.

41. Almussalam, T.H. Behavior of normal and high-strength concrete cylinders confined with E-glass/epoxy composite laminates. Compos. Part B 2007, 38, 629-639.

42. Wang, L.M.; Wu, Y.F. Effect of corner radius on the performance of CFRP-confined square concrete columns: Test. Eng. Struct. 2008, 30, 493-505.

43. Lin, C.; Li, Y. An effective peak stress formula for concrete confined with carbon fibre reinforced plastics. Can. J. Civ. Eng. 2003, 30, 882-889.

44. Owen, L.M. Stress-Strain Behavior of Concrete Confined by Carbon Fiber Jacketing. Master's Thesis, University of Washington, Seattle, WA, USA, 1998.

45. Mandal, S.; Hoskin, A.; Fam, A. Influence of concrete strength on confinement effectiveness of fiber-reinforced polymer circular jackets. ACI Struct. J. 2005, 102, 383-392.

46. Mander, J.B.; Priestley, J.N.; Park, R. Theoretical stress-strain model for confined concrete. ASCE J. Struct. Eng. 1988, 114, 1804-1826.

47. Saatcioglu, M.; Razvi, S.R. Strength and ductility of confined concrete. ASCE J. Struct. Eng. 1992, 118, 1590-1607.

48. Saatcioglu, M.; Razvi, S.R. Displacement-based design of reinforced concrete columns for confinement. ACI Struct. J. 2002, 99, 3-11.

49. Goodman, R.E. Introduction to Rock Mechanics; John Wiley \& Sons: Hoboken, NJ, USA, 1989.

50. Candappa, D.C.; Sanjayan, J.G.; Setunge, S. Complete triaxial stress-strain curves of high-strength concrete. J. Mater. Civ. Eng. 2001, 13, 209-215.

51. Dahl, K.K.B. A Failure Criterion for Normal and High Strength Concrete; Project 5, Rep. 5.6; American Concrete Institute: Farmington Hills, MI, USA, 1992.

52. Thériault, M.; Neale, K.W. Design equations for axially loaded reinforced concrete columns strengthened with FRP wraps. Can. J. Civ. Eng. 2000, 27, 1011-1020.

53. Lam, L.; Teng, J.G. Design-oriented stress-strain model for FRP-confined concrete. Constr. Build. Mater. 2003, 17, 471-489.

54. Campione, G.; Miraglia, N. Strength and strain capacities of concrete compression members reinforced with FRP. Cem. Concr. Compos. 2003, 25, 31-41.

55. Fahmy, M.F.M.; Wu, Z. Evaluating and proposing models of circular concrete columns confined with different FRP composites. J. Compos. 2010, 41, 199-213.

56. Li, G. Experimental study of FRP confined concrete cylinders. Eng. Struct. 2006, 28, 1001-1008.

57. Teng, J.G.; Jiang, T.; Lam, L.; Luo, Y.Z. Refinement of a design-oriented stress-strain model for FRP-confined concrete. ASCE J. Compos. Constr. 2009, 13, 269-278. 
58. Xie, J.; Elwi, A.E.; MacGregor, J.G. Mechanical properties of three high-strength concretes containing silica fume. ACI Mater. J. 1995, 92, 135-145.

59. Attard, M.M.; Setunge, S. Stress-strain relationship of confined and unconfined concrete. ACI Mater. J. 1996, 93, 432-442.

60. Wu, Y.F.; Zhou, Y. Unified strength model based on Hoek-Brown failure criterion for circular and square concrete columns confined by FRP. ASCE J. Compos. Constr. 2010, 14, 175-184.

61. Mohamed, H.; Masmoudi, R. Axial load capacity of concrete-filled FRP tube columns: Experimental versus predictions. ASCE J. Compos. Constr. 2010, 14, 231-243.

(C) 2013 by the authors; licensee MDPI, Basel, Switzerland. This article is an open access article distributed under the terms and conditions of the Creative Commons Attribution license (http://creativecommons.org/licenses/by/3.0/). 